Jerica Snoj

Inštitut za slovenski jezik Frana Ramovša ZRC SAZU

\title{
Kategorialne pomenske lastnosti in tipologiziranje slovarske večpomenskosti
}

\begin{abstract}
Kategorialni slovarski pomen je poleg denotativnega pomena prepoznan kot obvezna samostojna sestavina slovarskega pomena. Definiran je kot zbir kategorialnih pomenskih sestavin, obstoječih kot npr. lastnost spola pri samostalniku, vida pri glagolu ipd. Tako definiran kategorialni pomen omogoča, da se kot merilo za tipologiziranje slovarske večpomenskosti upoštevajo spremembe na ravni vsebovanih kategorialnih pomenskih sestavin pri motiviranjsko povezanih pomenih večpomenskega leksema (npr. $\mathrm{P}_{0}\{$ števno $\} \rightarrow \mathrm{P}_{\mathrm{m}}\{$ števno- $\}$ ). V sestavku predstavljena tovrstna tipologizacija samostalniškega gradiva se omejuje na upoštevanje dveh kategorialnih pomenskih lastnosti: števnosti in človeškosti.

In addition to the denotative meaning, the categorial lexical meaning is considered an immanent component of the lexical meaning. It is defined as the set of categorial semantic features, existing as gender in nouns, aspect in verbs etc. Defined in this way, the categorial meaning makes it possible for changes on the level of categorial semantic features (e.g., $\mathrm{P}_{0}\{+$ count $\} \rightarrow \mathrm{P}_{\mathrm{m}}\{-$ count $\}$ ) to be the criterion for the typologization of lexical polysemy. The paper presents such a typology of nouns, taking into consideration two categorial properties: countability and humanness.
\end{abstract}

\section{Kategorialni slovarski pomen, kategorialne pomenske lastnosti, katego-} rialne pomenske sestavine

1.1 Izhodišče za določitev kategorialnih pomenskih sestavin (KPS) je določeno pojmovanje obstoja in zgradbe slovarskega pomena: Slovarski pomen je vsebinska lastnost jezikovnega znaka, tj. temeljne poimenovalne enote slovarja (poimenovalni pol jezikovnega sistema). ${ }^{1}$ Vzpostavlja zvezo med zunajjezikovno stvarnostjo in jezikovnim izrazom. Pomen kot vsebina jezikovnega znaka se ponazarja $\mathrm{z}$ modelom hierarhično urejenega zbira vsebinskih lastnosti, ki omogočajo (jezikovnosistemsko) pomensko prepoznavnost tako znotraj (večpomenskega) leksema kot sploh v razmerju do drugih leksemov. ${ }^{2}$ To so pomenskorazločevalne vsebinske lastnosti, imenovane pomenske sestavine. Slovarski pomen, za uporabnika jezika nedeljiva celota, je torej v slovarskem pomenoslovju po teoriji pomenskosestavinske analize pojmovan kot razstavljiv na pomenske sestavine. ${ }^{3}$

\footnotetext{
${ }^{1}$ Tematika sestavka je bila v nekaterih prvinah predstavljena v magistrskem delu Tipologija slovarske večpomenskosti, Ljubljana, Filozofska fakulteta, 2002, mentorica red. prof. dr. Ada Vidovič Muha.

${ }^{2}$ Hierarhična strukturiranost slovarskega pomena se nanaša na ločevanje uvrščevalne pomenske sestavine (UPS) in razločevalnih pomenskih sestavin (RPS) pri endogenih leksemih in je bistvenega pomena znotraj pomenskosestavinske analize. Brez hierarhiziranosti je poskus s pomenskosestavinsko analizo zaobjeti celotni slovar danega jezika najbrž brezupen in metoda pomenskosestavinske analize v njenem absolutnem značaju ostaja uporabna za analiziranje zgolj omejenega števila izbranih leksemov. Prim. o tem Lyons 1977: 553.

${ }^{3} \mathrm{~V}$ pogledu osnovnih slovarskopomenoslovnih pojmov sestavek sledi strukturalnemu pojmovnemu sistemu na način, kot je s ponazorili iz slovenskega jezika in slovenskim izrazjem posredovan v Vidovič Muha 2000.
} 
1.2 Slovarski pomen vključuje denotativni pomen in kategorialni pomen kot obvezna pomena in konotativni pomen kot neobvezni pomen. $\mathrm{V}$ skladu $\mathrm{s}$ tem, da sta kategorialni in denotativni pomen enakovredna $\mathrm{v}$ sestavi slovarskega pomena, so kategorialne pomenske lastnosti definirane analogno denotativnim pomenskim lastnostim.

Denotativni pomen je abstrakcija skupine istovrstnih denotatov in $\mathrm{v}$ jezikovnem sistemu (slovarju) obstoji kot abstrakten ustreznik predmetnosti, poimenovane $\mathrm{z}$ dano slovarsko enoto. Uresničen je preko denotativnih pomenskih sestavin, tj. denotativnih pomenskih lastnosti, ki so pomenskorazločevalne.

Vzporedno temu kategorialni pomen znotraj slovarskega pomena obstoji kot zbir tistih pomenskih lastnosti, ki danemu slovarskemu pomenu omogočajo in določajo opravljanje čisto določene skladenjske vloge. Prepoznavnost teh lastnosti, imenovanih kategorialne pomenske lastnosti ( $\mathrm{v}$ nadaljevanju KPL), izhaja iz skladenjske vloge, $\mathrm{s}$ katero so KPL $v$ dialektičnem razmerju: skladenjska vloga je prepoznavna preko KPL, te pa izhajajo iz skladenjske vloge. Skladenjskofunkcijska opredelitev kategorialne pomenske lastnosti vzpostavlja povezavo med pojmoma kategorialna pomenska lastnost in besedna vrsta; kategorialne pomenske lastnosti imajo vlogo besednovrstnega ločevanja. Določena množica poimenovalnih prvin je namreč preko vsebovanih kategorialnih pomenskih lastnosti nosilka določene skladenjske vloge in s tem konkretizacija določene besedne vrste. Tako je za kategorialni pomen ugotovljeno, da je uresničen preko pomenskih sestavin, in sicer kategorialnih pomenskih sestavin (KPS), tj. kategorialnih pomenskih lastnosti, ki so pomensko razločevalne na ravni razlikovanja skladenjskih vlog oz. besednih vrst.

1.3 Za ponazoritev vloge kategorialnega pomena in obstoja kategorialne pomenske lastnosti preko kategorialnih pomenskih sestavin vzemimo npr. samostalniško kategorialno lastnost podspol človeško: Tisto, kar odloča o usposobljenosti danega slovarskega pomena za skladenjsko vlogo prvega delovalnika (D1) oz. osebka in kar odloča o paradigmatski uvrstitvi danega pomena $\mathrm{k}$ nadpomenki $k d o$ ali $\mathrm{k}$ njenemu polarnemu nasprotju kar v t. i. pomenski piramidi, je v slovarskem pomenu prisotna pomenska sestavina človeško+ (za uvrstitev h $k d o$ ) oz. človeško- (za uvrstitev h kar). Obe pomenski sestavini, človeško+ in človeško-, ki sta medsebojno $\mathrm{v}$ privativnem razmerju, znotraj samostalniškega pomena uresničujeta kategorialno pomensko lastnost človeško. Kategorialne pomenske lastnosti so torej analogno denotativnim pomenskim lastnostim $\mathrm{v}$ danem slovarskem pomenu konkretizirane kot kategorialne pomenske sestavine.

\section{Kategorialne pomenske sestavine $\mathrm{v}$ vlogi merila tipologiziranja slovarske večpomenskosti}

2.1 Pri nekaterih motiviranjsko povezanih pomenih je ugotovljeno, da se motivirajoči in motivirani pomeni tipsko razlikujejo prav glede na vsebovane KPS. Npr. tip sinekdohne pomenske spremembe 'drevo' $\rightarrow$ 'les drevesa' (bukev, hrast, češnja, smreka, evkaliptus itd.) regularno vključuje tudi zamenjavo KPS števno+ ('drevo') s KPS števno- ('les').

2.1.1 Načeloma so spremembe med tvorbno (motiviranjsko) povezanima pomenoma, do katerih pride na ravni KPS, s stališča posledic za pomen dveh vrst: Če sprememba KPS povzroči ukinitev določene KPL, se spremeni besednovrstna pri- 
padnost danega pomena. To hkrati pomeni izstop pomena iz danega leksema in vstop v novi leksem oziroma vzpostavitev novega leksema. Tipični primer za to je metaforična povedkovna raba samostalnika, pri kateri samostalnik izgubi kategorialno lastnost spola (imeti dobrega učitelja $\rightarrow$ Ona je preveč učitelj, zato ni vedno prijetno jo poslušati). S stališča izgube kategorialne pomenske lastnosti spola sprememba predstavlja prehod $\mathrm{v}$ novo besedno vrsto in sodi $\mathrm{v}$ besedotvorje. ${ }^{4}$

2.1.2 Druga vrsta sprememb poteka znotraj določene kategorialne pomenske lastnosti: KPL $\{\mathrm{KPSx}+\} \rightarrow \mathrm{KPL}\{\mathrm{KPSx}-\}$ ali v nasprotni smeri. KPL, v motivirajočem pomenu uresničena kot $\mathrm{KPSx}+$, se $\mathrm{v}$ motiviranem pomenu uresničuje preko $\mathrm{KPSx}-$, tj. svoje nasprotnice iz privativnega razmerja. To povzroči regularno spremembo slovarskega pomena. Pojav sodi v pomenotvorje. Primer: čéšnja -e ž: 'drevo' \{števno+\} požagati češnjo $\rightarrow$ 'les’ \{števno-\} pohištvo iz češnje. Ta vrsta sprememb na ravni KPS je pomembna za tipologijo večpomenskosti.

2.2 Obe vrsti sprememb ((1) KPL $\rightarrow \varnothing$, (2) KPL $\{\mathrm{KPSx}+\} \longleftrightarrow$ KPL $\{\mathrm{KPSx}-\})$ sta omogočeni $\mathrm{z}$ dvojno vlogo KPS: V prvem primeru so KPS uresničevalke KPL in s tem nosilke besednovrstne pripadnosti; v drugem primeru nastopajo KPS kot nosilke znotrajleksemske medpomenske razločevalnosti. V tej vlogi so KPS hkrati lahko merilo za tipologiziranje slovarske večpomenskosti. Motiviranjsko povezane slovarske pomene je namreč mogoče razvrščati glede na to, katero spremembo na ravni KPS vključujejo.

Posledice sprememb na ravni kategorialnih pomenskih sestavin (KPS)

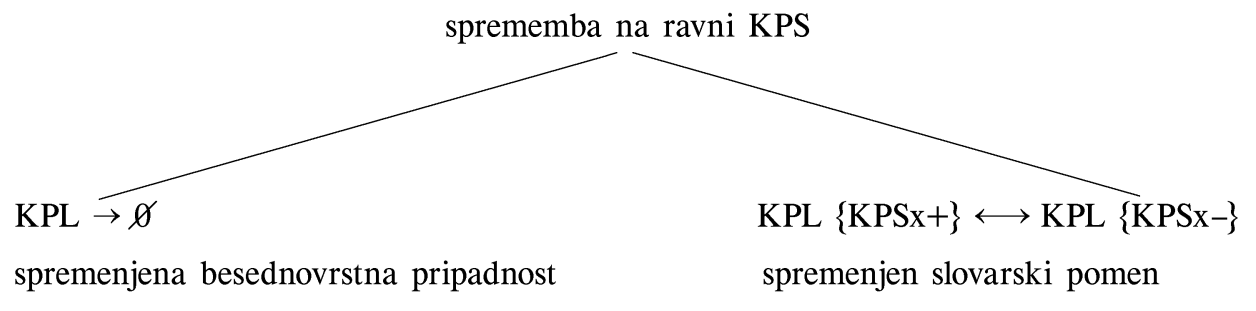

\section{Specifičnost tipologiziranja slovarske večpomenskosti glede na KPS}

3.1 KPS so sicer del denotativnega pomena, vendar razločevalno določene preko skladenjske vloge in zato $\mathrm{v}$ svoji določenosti proste povezovanja $\mathrm{z}$ zunajjezikovnim. ${ }^{5}$ Zaradi te njihove značilnosti predstavljajo spremembe kategorialnih pomenskih lastnosti, do katerih pride pri neposredni znotrajleksemski pomenski izpeljavi $\mathrm{P}_{0} \rightarrow \mathrm{P}_{\mathrm{m}}$, posebno merilo tipologiziranja večpomenskosti, $\mathrm{v}$ primerjavi $\mathrm{z}$ drugimi merili čisto jezikovnosistemsko in najbolj abstraktno.

\footnotetext{
${ }^{4}$ Prim. Vidovič Muha 2000: 125, 127, 145, 148.

${ }^{5}$ Kako pomembno je sicer pri obravnavi slovarskega pomena upoštevanje dvojnosti jezikovno - zunajjezikovno, je ponazarjalno ubesedeno v šaljivem povzetku, kot ga navaja I. Mel'čuk: »Bertrand Russel once wrote: »No one can understand the word cheese unless he has a nonlinguistic acquaintance with cheese «, i. e. unless he has seen it, smelled it and eventually sunk his teeth into it. But to that Roman Jakobson rightly retorted that "no one can understand the word cheese un less he has an acquaintance with the meaning assigned to this word in the lexical code of English «. Both great semioticians are right: to fully understand a linguistic expression one needs a serious nonlinguistic exposure to its referent (the thing denoted by it) AND a lingustic explication of its meaning.« (Žic-Fuchs 1991: 59)
} 
Povedano s primerom: Celotna množica samostalniških pomenov je razvrstljiva glede na to, ali znotraj kategorialne pomenske lastnosti človeško samostalniški pomen vsebuje KPS človeško+ ali KPS človeško-. S tem se vsi samostalniški pomeni (ne glede na vsakokratni različni denotativni pomen) delijo v dve skupini: (1) v skupino $\mathrm{z}$ nadpomenko človek (ali $\mathrm{v}$ nekaterih primerih človekoliko) in najvišjo UPS kdor v t. i. pomenski piramidi in (2) v skupino vseh ostalih samostalniških pomenov z ustrezno UPS kar. Kategorialno pomensko lastnost človeško lahko glede na to pojmujemo kot skladenjsko utemeljen pomenskosestavinski abstraktni ustreznik vseh tistih denotativnopomenskih lastnosti samostalniških pomenov, ki s svojo prisotnostjo omogočajo uvrstitev danega pomena $\mathrm{k}$ nadpomenki človek, $\mathrm{s}$ svojo odsotnostjo pa to onemogočajo in zahtevajo uvrstitev $\mathrm{h}$ kar. Na načelni ravni je torej v kategorialnih pomenskih lastnostih mogoče videti neke vrste skupne imenovalce vseh denotativnih pomenov. $\mathrm{V}$ primerjavi $\mathrm{z}$ denotativnim pomenom se kategorialne pomenske lastnosti kažejo kot tiste, ki so na ravni prisotnosti pozitivnega člena iz dane dvojice KPS (npr. števno+) ali prisotnosti negativnega člena (npr. števno-) aktualne v vseh slovarskih pomenih določene besedne vrste in ki zagotavljajo usposobljenost pomena za opravljanje določene skladenjske vloge ne glede na denotativnopomensko raznolikost znotraj določene besedne vrste. Kategorialne pomenske lastnosti predstavljajo skupni imenovalec vseh slovarskih pomenov, pripadajočih določeni besedni vrsti. Tako morajo npr. biti vsi samostalniški pomeni opredeljivi glede na to, ali vsebujejo KPS človeško+ ali človeško-, živo+ ali živo-, števno+ ali števno-, m. spol ali ž. spol ali s. spol (sklanjatev kot kategorialna pomenska lastnost). Če niso opredeljivi glede naštetih lastnosti, niso samostalniški pomeni.

3.2 Sprememba znotraj KPL, uresničena $\mathrm{z}$ zamenjavo KPS v smislu KPS $+\rightarrow$ KPS- (npr.: čéšnja -e ž: požagati češnjo 'drevo' \{števno+\} $\rightarrow$ pohištvo iz češnje 'les' \{števno-\}), nakazuje prehod iz ene paradigmatsko urejene množice denotativnih pomenov v drugo množico; dana sprememba povezuje dva razreda denotativnih pomenov, v katerih je dani večpomenski leksem hkrati prisoten s posameznima motiviranjsko neposredno povezanima pomenoma. ${ }^{6}$ Gledano s stališča znotrajleksemske medpomenske spremembe, je to znotrajleksemska povezava paradigmatsko ((so)pomensko v najširšem smislu) samostojno organiziranih različnih razredov denotativnih pomenov. Primer: Pomena 'drevo' in 'les drevesa' samostalniškega leksema čéšnja -e ž, različna v kategorialni lastnosti števnosti ('drevo' števno+, 'les' števno-), sta pomena iz razredov denotativnih pomenov 'predmeti' in 'snovi'. Tipologiziranje večpomenskosti glede na znotrajleksemske spremembe kategorialnih pomenskih lastnosti torej posreduje vpogled $\mathrm{v}$ to, kateri razredi kategorialno različnih denotativnih pomenov so povezani znotraj leksemov danega jezika.

3.3 Značaj kategorialnosti pri KPL se torej nanaša ne dvoje medsebojno neločljivo povezanih danosti, izhajajočih iz skladenjske vloge endogenega leksema: 1. Vsak slovarski pomen ima svoj stalni, končni nabor kategorialnih pomenskih lastnosti, utemeljen v skladenjski vlogi, ki jo je zmožen opravljati, in ki je določen za celotno besednovrstno kategorijo, ki ji pomen pripada. 2. KPS, uresničujoče dano KPL, so na način prisotnosti pozitivnega ali negativnega člena iz danega privativnega razmerja KPS udeležene pri prav vseh pomenih, pripadajočih določeni besedni vrsti. Značaj

${ }^{6}$ Pojem paradigmatsko urejena množica pomenov je mišljen v skladu s pojmovanjem paradigmatike, vertikalnosti nasproti sintagmatiki, horizontalnosti pri Jakobsonu. Prim. Jakobson 1989. 
kategorialnosti je torej povezan $\mathrm{z}$ dialektičnim razmerjem med kategorialnimi pomenskimi lastnostmi in skladenjsko vlogo. Končnost in obvezna prisotnost danega nabora kategorialnih pomenskih lastnosti znotraj dane besedne vrste omogočata objektivnost tipologije slovarske večpomenskosti, ki ima KPL za klasifikacijsko merilo. Tipologiziranje večpomenskosti na osnovi sprememb KPL pomeni tipologiziranje na docela znotrajjezikovni, jezikovnosistemski ravni (različno od tipologiziranja npr. po pomenskih skupinah, ki do neke mere vselej odraža tudi zunajjezikovne danosti).

3.4 Nekatere kategorialne pomenske lastnosti oz. kategorialne pomenske sestavine se na izrazni ravni do določene mere predvidljivo povezujejo $\mathrm{z}$ določenimi sintagmatskimi kategorialnimi lastnostmi. ${ }^{7}$ Tako predvidljivost predstavlja npr. pojav, da se znotraj kategorialne pomenske lastnosti živost pri samostalnikih moškega spola $\mathrm{v}$ ednini KPS živo- predvidljivo uresničuje $\mathrm{v}$ prekrivnosti oblike tožilnika $\mathrm{z}$ imenovalnikom, KPS živo+ pa v predvidljivi prekrivnosti oblike tožilnika z rodilnikom.

\section{Kategorialne pomenske lastnosti samostalnika}

4.0 Samostalnik kot besedna vrsta vključuje kategorialne pomenske lastnosti spol, podspola živost in človeškost ter števnost. ${ }^{8}$ Za prepoznavnost teh lastnosti je odločilno osebkovo mesto $\mathrm{v}$ stavku. Znotraj samostalniškega slovarskega pomena so te lastnosti v razmerju hierarhiziranega vključevanja, pri katerem lastnost spola omogoča vse ostale:

\section{SPOL $\{$ ŠTEVNOST $\{$ ŽIVOST $\{$ ČLOVEŠKOST $\}\}\}$}

Za tipologijo slovarske večpomenskosti sta pomembni zlasti kategorialni pomenski lastnosti števnost in človeškost. ${ }^{9}$ Sprememba kategorialnih pomenskih lastnosti je lahko eno od tipologizirajočih meril pri vseh vrstah znotrajleksemskih medpomenskih razmerij (metaforičnih, metonimičnih in sinekdohnih in tudi posredno motiviranih), izvzemši znotrajleksemsko medpomensko razmerje pomenske vsebovanosti ali posplošujoče metafore..$^{10}$

\footnotetext{
${ }^{7}$ Sintagmatske kategorialne lastnosti, imenovane tudi skladenjske kategorialne lastnosti ali slovnične lastnosti, so tiste, s katerimi se dana besedna vrsta ločuje od drugih v besedilu. Pri samostalniku so to število, sklon, sklanjatev. Poimenovane so kategorialne, ker zadevajo celotno besednovrstno kategorijo. (Vidovič Muha 2000: 38) Od sintagmatskih kategorialnih lastnosti se slovarske kategorialne lastnosti ločijo po tem, da obstoje v slovarskem pomenu - so sestavina slovarskega pomena - neodvisno od besedila, čeprav relevantne tudi v besedilu. (Prav tam: 30)

${ }^{8}$ Sklanjatev kot kategorialna lastnost je pojmovana kot implicirana v lastnosti spola. (Vidovič Muha 2000: 34)

${ }^{9}$ Kategorialna pomenska lastnost živost $\mathrm{v}$ tukajšnji obravnavi ni načrtno obdelana, ker je sprememba te lastnosti kot večpomenskostna sprememba večinoma prisotna pri posredno motivirani večpomenskosti, pri pomenski vsebovanosti sprememb kategorialnih pomenskih lastnosti ne more biti, pri metafori pa je večinoma vključena $\mathrm{v}$ obravnavani večpomenskosti tipa človeško$\longleftrightarrow$ človeško+. Zaradi predvidljive formalne izraženosti samo pri samostalnikih moškega spola (tožilnik = rodilnik) se živost navadno pojmuje kot skladenjska (sintagmatska) lastnost. Kategorije nepredvidljive povezanosti živo+ s pomeni za 'nebitje' pa so zaradi zanimivosti z normativnega stališča že razmeroma dobro evidentirane. (Toporišič 2000: 277; prim. še oznaka živ. pri samostalnikih v slovarju Slovenskega pravopisa 2001)

${ }^{10}$ Nespremenljivost kategorialnih pomenskih lastnosti pri pomenski vsebovanosti (motivirajoči pomen je v vlogi nadpomenke nasproti motiviranemu pomenu; npr. moški: ‘človek moškega spola,
} 
Znotrajleksemsko medpomensko razmerje, vključujoče spremembo kategorialne pomenske lastnosti človeškost

lisica -e $\check{z}$

$\mathrm{P}_{0}=$ 'žival'; kategorialna pomenska sestavina motivirajočega pomena $\mathrm{KPS}_{0}=$ človeško-

$\mathrm{P}_{\mathrm{m}}=$ 'ženska'; kategorialna pomenska sestavina motiviranega pomena $\mathrm{KPS}_{\mathrm{m}}=$ človeško+

$\begin{array}{ll}\mathrm{L} & \mathrm{P}_{0}\left\{\mathrm{KPS}_{0}\right\} \\ & \mathrm{P}_{\mathrm{m}}\left\{\mathrm{KPS}_{\mathrm{m}}\right\}\end{array}$

\section{1 Števnost}

4.1.1 Števnost je kot kategorialna pomenska lastnost samostalnika konstitutivna lastnost samostalniškega slovarskega pomena. Števnostna pomenska sestavina se povezuje s tisto lastnostjo denotata oz. poimenovane zunajjezikovne danosti, ki odloča o načinu kolikostnega določanja imenovane stvarnosti. Pri tem je bistveno razlikovanje, ali je to določanje možno s štetjem ali ne. Če je denotat povezan z zunajjezikovno danostjo, ki se kolikostno določa s štetjem, se to v slovarskem pomenu kaže v KPS števno+, če pa se kolikostno določa s tehtanjem ali kakšnim drugim merjenjem (abstraktni pomeni), se to kaže v KPS števno-.."

4.1.2 Izraženost števnosti se povezuje s slovničnim številom, tj. specializirano slovnično obliko za izražanje kolikostne določenosti. Pri samostalniku je slovnično število formalna lastnost za izražanje števnosti. Pri danem pomenu slovnična troštevilskost z regularnim pomenom ednine ('eno, posamezno') in množine ('pomnoženo posamezno') predvidljivo izraža KPS števno+, medtem ko izključenost troštevilskosti (tj. v primerih, ko je možna samo edninska ali samo množinska oblika) ali posebni pomen troštevilskosti (vrstni pomen množine) predvidljivo izraža KPS števno-. ${ }^{12}$

4.1.3 $\mathrm{V}$ doslejšnjih obravnavah pomenske vrednosti števnosti v slovenskem jeziku sama števnost ostaja večinoma nedoločena, omenjajo se zlasti besedilne značilnos-

navadno odrasel' - 'človek moškega spola, navadno odrasel, ki ima vlogo partnerja') in posplošujoči metafori (npr.: baba: slabš. 'ženska z negativno vlogo' - ekspr. 'ženska sploh') je določujoča lastnost teh dveh pomenotvornih sprememb v primerjavi z ostalimi tipi, definiranimi na osnovi tipskih sprememb v pomenskosestavinski zgradbi. Ta skupna značilnost, utemeljena v nad- oziroma podpomenskem razmerju med povezanima pomenoma, predstavlja še eno sorodnost med pomenskima razmerjema pomenske vsebovanosti in posplošujoče metafore.

${ }^{11}$ Določitvi števnosti je na tem mestu namenjeno nesorazmerno veliko pozornosti (glede na to, da se kategorialne pomenske lastnosti obravnavajo samo kot merilo za tipologiziranje slovarske večpomenskosti in ne same po sebi), ker se pri delovni določitvi te kategorialne pomenske lastnosti ni mogoče zadostno sklicevati na kakšno že obstoječo definicijo, ki bi to kategorialno pomensko lastnost ustrezno predstavljala s stališča njene vloge znotraj slovarskega pomena in s stališča izraženosti v slovenskem jeziku.

${ }^{12}$ Obstoj in izraženost kategorije števnosti sta $v$ vsakem jeziku specifična, kar mora zlasti upoštevati slovaropisje. Ta specifičnost obstoja je ob ustrezni slovaropisni obravnavi doslej najbolj razvidna v slovarju Collins Cobuild English Language Dictionary (prva izdaja 1987), in to tako v označevanju te kategorialne lastnosti pri posameznih samostalniških leksemih kot v definicijskem določanju te kategorialne lastnosti (specialni iztočnici N COUNT (959) in N UNCOUNT (985)). 
ti, povezane s to kategorialno pomensko lastnostjo, in pomenskost slovničnega števila množine. ${ }^{13} \mathrm{~V}$ definicijah števnosti se s slovarskopomenoslovnega stališča pogreša razlikovalna določitev števnosti kot slovarskopomenske kategorije in slovničnega števila kot slovnične kategorije. ${ }^{14}$ Ohlapno so obravnavane predvidljive možnosti povezovanja in izražanja te kategorialne pomenske lastnosti $\mathrm{z}$ določenimi oblikami slovničnega števila. ${ }^{15}$ Razmeroma ustaljeno poimenovanje števni samostalniki, neštevni samostalniki (Toporišič 1992; Toporišič 2000) se nanaša na uresničenost kategorialne lastnosti števnosti v izhodiščnem pomenu, kar je za pomenoslovno obravnavo večpomenskosti premalo natančno. Pri obravnavi slovarske večpomenskosti, upoštevajoči kategorialno pomensko lastnost števnost kot tipologizirajoče merilo, je namreč relevantna prisotnost določene števnostne KPS znotraj vsakega slovarskega pomena posebej, ne glede na to, ali je pomen izhodiščni pomen ali motivirani pomen.

4.1.4 Števnost je tako kot vse kategorialne pomenske lastnosti utemeljena s skladenjsko vlogo, za katero je usposobljen dani slovarski pomen. Za določitev njene svojskosti znotraj ostalih samostalniških kategorialnih lastnosti, ki so v službi iste skladenjske vloge, pa se kaže uporaben pogled na tisto lastnost denotatov, glede na katero so ti razvrščeni v polarno nasprotni množici s KPS števno+ in KPS števno-.

Ta pogled razkriva, da se slovarski pomen, ki vsebuje KPS števno+, povezuje z denotatom, ki se nanaša na ločljivo zunajjezikovno danost. (Crystal 1991: 87) Poimenovanje posamezne take danosti je večinoma vezano na slovnično število ednino (svinčnik), slovnični števili dvojina in množina pa pri teh pomenih praviloma pomenita podvojitev in pomnožitev posamičnega (svinčniki 'več svinčnikov'). Posebnost $\mathrm{v}$ tem pogledu predstavljajo pomeni samomnožinskih samostalnikov (vrata, vilice), ki se prav tako povezujejo $\mathrm{z}$ denotatom, nanašajočim se na ločljivo zunajjezikovno da-

${ }^{13}$ Slovenska slovnica omenja števnost pri razdelku Vrste samostalniških besed (Toporišič 2000: 275): »Občna imena delimo po pomenu (podč. J. S.) na števna in neštevna, npr. potok - lepota, železo - grmovje (pojmovna, snovna, skupna). Razlika se lepo vidi v množini: potoki $=$ več potokov, lepote $=$ več vrst lepote. Iz neštevnosti vodi prehod v števnost: tri železa = 'trije kosi železa'; tak prehod je lahko stilno opazen (pri Prešernu: plesale lepote Ljubljane so cele).« Kot utemeljitev delitve na števna imena in neštevna imena je imenovan pomen, brez neposredne enotne opredelitve, katere vrste pomen pripada kateri skupini; pojmovno, snovno in skupno bi moralo imeti naveden skupni imenovalec neštevno nasproti vsemu števnemu; to nasprotje je namreč konstitutivno za obstoj kategorialne pomenske lastnosti števnosti. Razlika med števnostno različnimi samostalniki je torej v slovnici pojasnjena posredno, s ponazorilom različnega pomena slovničnega števila množine, tj. na ravni sintagmatskih kategorialnih lastnosti. Omenjen je prehod iz neštevnosti v števnost, ne pa tudi nasprotna možnost (prikazana $\mathrm{z}$ besedilnim ponazorilom), in to brez jasnejše opredelitve, da je to sprememba slovarskega pomena oz. tvorba novega pomena. - Enciklopedija slovenskega jezika (Toporišič 1992: 324) števnost opisuje kot lastnost samostalnikov tako, da navaja dobesedno za merilo števnosti štetje troštevilskih samostalnikov z glavnimi števniki in štetje samomnožinskih z ločilnimi števniki, za merilo neštevnosti pa, da se s takimi števniki »ne izraža količina istega, ampak različnega«, torej raznovrstnost. (Toporišič 1992: 324) - Slovar Slovenskega pravopisa 2001 navaja oznake snovn., skupn., pojm. za števno- pri posameznih pomenih samostalnika, pomeni, ki vsebujejo KPS števno+, so brez oznake; pač pa imajo oznako števn. motivirani pomeni, tvorjeni iz pomenov s KPS števno-. Slovar Slovenskega pravopisa 2001 sicer ne prinaša slovarskopomenoslovne definicije števnosti, niti ne posreduje eksplicitnega podatka o tem, kako je sistemsko zamišljeno prikazovanje števnosti znotraj specifične zasnove tega slovarja.

${ }^{14}$ Izjemo v tem pogledu predstavlja Černelič 1974, ki razvidno ločuje med števnostjo kot slovarskopomensko kategorijo in slovničnim številom kot slovnično kategorijo.

${ }^{15}$ Najobsežneje obdelano pri Hočevar Gregorič 1995. 
nost, le da pri njih ne more biti zgoraj navedene predvidljive povezave med kategorialno pomensko lastnostjo števno+ in ednino, niti se pomnožitev posamičnega ne more izražati z množino; množinska oblika je pri teh samostalnikih namreč edina možna oblika.

Denotati samostalniških pomenov, ki vsebujejo KPS števno-, so v primerjavi z gornjimi (vsebujočimi KPS števno+) bolj raznoliki: lahko se povezujejo z nematerialno neločljivo zunajjezikovno danostjo (abstraktna predmetnost, npr. žalost); ali pa z materialno danostjo, ki je iz kontinuuma neločljivih delcev (snov, npr. voda; Crystal 1991: 87) ali ki nastopa kot skupnost s stališča poimenovanja neindividualiziranih, medsebojno povezanih enakih enot (skupno, npr. listje, pohištvo). Poimenovanje te vrste zunajjezikovnih danosti je večinoma vezano na slovnično število ednino, množina pa glede na značaj pripadajoče predmetnosti ne more pomeniti pomnožitve posamičnega, zato lahko dobi druge pomene (pri imenih snovi 'vrsta snovi’, pri imenih lastnosti 'nosilec lastnosti' itd.). Posebnost tudi med temi predstavljajo samomnožinski samostalniki, pri katerih ne more biti predvidljive povezave med slovničnim številom ednino in KPS števno-, niti ne predvidljivih povezav med slovničnim številom množino in spremenjenimi pomeni.

4.1.5 Pri tipologiziranju slovarske večpomenskosti glede na KPL števnost se tipi znotrajleksemskih neposrednih pomenotvornih povezav razvrščajo glede na to, katero zamenjavo števnostne KPS vključujejo: KPS števno+ $\rightarrow$ KPS števno- (npr. 'drevo' $\rightarrow$ 'les drevesa' (̌̌ešnja)), KPS števno- $\rightarrow$ KPS števno+ (npr. 'snov' $\rightarrow$ 'predmet iz te snovi’ (̌̌elezo)) itd.

\section{2 Človeškost}

4.2.1 Človeškost kot kategorialna pomenska lastnost samostalnika je opredeljena s pomenskoskladenjskim mestom prvega delovalnika (vršilec dejanja, nosilec lastnosti, nosilec stanja) oziroma strukturnoskladenjskim mestom osebka v stavku.

Samostalniški slovarski pomeni imajo glede na prisotnost KPS človeško+ ali KPS človeško- táko UPS, ki je v pomenski piramidi podrejena bodisi nadpomenski UPS $k d o$ (v primeru KPS človeško+) bodisi UPS kaj (v primeru KPS človeško-).

Glede na to, da je kategorialna lastnost človeškost znotraj hierarhične ureditve samostalniških KPS nižje kot lastnost števnost (tj. vsi samostalniški pomeni se najprej delijo na take s KPS števno+ in take s KPS števno-, šele tisti s KPS števno+ so lahko tudi človeško+), predstavljajo posebnost samostalniki, ki so skupna imena, nanašajoča se na skupine oseb (dijaštvo, vojaštvo, aristokracija, otročad ipd.). ${ }^{16}$

Kategorialna pomenska lastnost človeško nima lastnega formalnega izraza (podobno kot glagolska vezljivost).

$\mathrm{V}$ tem je mogoče videti razlog, zakaj kategorialna pomenska lastnost človeškost v okviru slovaropisnih obravnav ni deležna velike pozornosti: ker pač ne vključuje vprašanja, s katerim formaliziranim slovaropisnim sredstvom (oznako, pojasnilom ipd.) slovaropisno ustrezno prikazovati to pomensko danost $\mathrm{z}$ ozirom na $\mathrm{z}$ njenim uresničevanjem povezane sintagmatske lastnosti; saj $\mathrm{v}$ ta namen običajno zadošča izbira ustrezne nadpomenke iz podmnožice $\mathrm{z}$ vrhovno nadpomenko $k d o$.

${ }^{16}$ Prisotnost KPS števno- pri skupnih imenih onemogoča normalno uresničitev KPS človeško+. Morda bi primere s slovarskim pomenom tipa 'skupina oseb' označili kot posredno vsebujoče KPS človeško+ (»posredno« zaradi tega, ker gre za skupino oseb, ne katero koli skupino). 
Še najpogosteje se človeškost omenja v povezavi s samostalnikom v povedkovni rabi (Kozlevčar 1968), in sicer zato, ker $\mathrm{v}$ povedkovni rabi predstavljajo posebno skupino samostalniki, ki v izhodiščnem pomenu vsebujejo kategorialno pomensko sestavino človeško+, v povedkovni rabi pa jo hkrati z ukinitvijo samostaniškosti izgubijo. - Vprašanje izraženosti pomenske lastnosti človeško je zastavljeno - sicer $\mathrm{v}$ povsem drugem okviru, $\mathrm{v}$ okviru pomenoslovne teorije znotraj tvorbene slovnice - tudi v Orešnik 1972, in sicer v zvezi z opisi relacijskih sistemov. V opisih relacijskih sistemov naj bi bili opomenjeni t. i. zahtevki glede sobesedila (angl. contextual properties). Zaplet v zvezi z oznako +človek je opisan takole: $»$ Npr. ob relacijskem sistemu $\{\leftrightarrow$ poročen\} naj bi bil zahtevek, da morata semantični definiciji a in $b$ v zapisu stavčnega pomena a $. r . b$, kjer vsebuje $r$ eno od semantičnih oznak sistema »biti poročen«, vsebovati semantično oznako +človek. Tako bi se formaliziralo intuitivno spoznanje, da je npr. stavek *Misel je poročena s kamnom z vidika pomena v normalnem slogu nepravilen. - Po konkurenčnem stališču sodijo taki zahtevki do sobesedila v skladnjo. Za zdaj je vprašanje odprto.« V opombi k temu mestu avtor dodaja: «Kdor trdi, da sodi npr. tu navedeni zahtevek glede sobesedila $\mathrm{v}$ skladnjo, uvaja $\mathrm{v}$ teorijo sintaktično oznako +človek. Uvedbo kateregakoli konstrukta v skladnjo utemelji predlagatelj tako, da dokaže, da je potrebno novi konstrukt omeniti v vsaj enem sintaktičnem pravilu slovnice. Kar zadeva oznako +človek, mi za zdaj ni znano, da bi jo bilo treba omenjati v kakem sintaktičnem pravilu.« (Orešnik 1972: 43)

4.2.2 Pri tipologiziranju slovarske večpomenskosti glede na KPL človeško se tipi medpomenskih povezav razvrščajo glede na spremembo: KPS človeško- $\rightarrow$ KPS človeško+ (npr. 'dejanje' $\rightarrow$ 'vršilec dejanja' (grábě̌ -a m)). ${ }^{17}$

\section{Tipologija samostalniških znotrajleksemskih medpomenskih povezav gle- de na pomenotvorne spremembe na ravni kategorialnih pomenskih sestavin}

5.1 Izhodišče za sledečo tipologijo je bila neposredno na slovarskem gradivu izvedena popolna tipologizacija samostalniške večpomenskosti glede na ugotovljene tipe pomenskosestavinske dinamike (pomenska vsebovanost in pomenski prenosi (metonimija s sinekdoho in metafora)). ${ }^{18}$ Tako izvedena tipologija je spodbudila nadaljnje tipologiziranje glede na spremembe, ugotovljene na ravni KPS. Tako se je npr. za množico metonimičnih medpomenskih povezav pokazala možnost, da se celotna skupina posebej razčleni glede na to, do katerih sprememb na ravni KPS pride pri izpeljavi motiviranega pomena iz osnovnega pomena.

Večpomenskost je bila za potrebe tipologizacije analizirana $\mathrm{z}$ metodo pomenskosestavinskih opisov pomenskih dvojic, povezanih $\mathrm{z}$ neposredno motivacijo, na način: pomenotvorno izhodišče (motivirajoči pomen, izhodiščni pomen, osnovni pomen) $\rightarrow$ pomenotvorni rezultat (motivirani pomen, tvorjeni pomen). Primer: železnína -e ž ‘izdelki iz železa, kovin' (KPS števno-, skupno) $\rightarrow$ 'prodajalna z izdelki iz železa, kovin' (KPS števno+); prevod pomenske dvojice na raven pomenskih skupin oz. tipa medpomenske povezave: 'predmeti' $\rightarrow$ 'prodajalna predmetov'. Iz primera je razvidno, kako je za vsak pomen posebej ugotovljena kategorialna pomenska sestavina, uresničujoča kategorialno pomensko lastnost.

Tak opis sicer še vedno predstavlja večpomenskost kot statično lastnost leksema, vendar s poudarkom na spremembi, ki jo doživi zgradba motivirajočega pomena pri tem, ko opravlja vlogo izhodišča za tvorjeni pomen.

\footnotetext{
${ }^{17}$ Sprememba KPS človeško+ $\rightarrow$ KPS človeško- (npr. 'vršilec dejanja' $\rightarrow$ 'sredstvo' (hlapec -pca m) v obdelanem gradivu ni bila evidentirana.

${ }^{18}$ Podrobneje o zasnovi in gradivski izvedbi te tipologizacije gl. v Snoj 2004: 71-102.
} 
5.2 Ugotovljena tipologija, upoštevajoča spremembe kategorialnih pomenskih sestavin večpomenskih samostalnikov, je $\mathrm{v}$ spodnjem prikazu organizirana $\mathrm{v}$ tem redu: (1) števno+ $\rightarrow$ števno-, 2. števno- $\rightarrow$ števno,+ 3 . števno- $\{$ pojmovno $\} \rightarrow$ števno- $\{$ skupno\}, 4. števno- $\{$ pojmovno\} $\rightarrow$ števno- \{snovno\}. Sledijo povezave, vsebujoče spremembo znotraj KPL človeško. Navedbi posamezne tipske povezave (npr. 'predmeti' $\rightarrow$ 'prodajalna s predmeti') so pripisani leksemi, ki vsebujejo navedeno pomensko povezavo (npr. $\mathrm{h}$ gornji dvojici 'predmeti' $\rightarrow$ 'prodajalna s predmeti': bižuterija, galanterija, delikatesa, kramarija, manufaktura, optika, pozamenterija, špecerija, železnina). ${ }^{19}$

5.3.1 Pomenske izpeljave, vključujoče spremembo KPS števno+ $\rightarrow$ števnoMetonimični pomeni

1. 'predmet' - 'individualizirana skupnost predmetov' (števno- = skupno) (bukev, bor ('drevo' - 'drevje'); govedo ('Žival' - 'več živali'))

2. 'posoda' - 'vsebina posode' (števno- = snovno) (konzerva, kozarec, krožnik, lonec, majolika, skleda, skodela, skodelica, sod, steklenica, škaf, škatla, vrč, zaboj)

3. 'užitni del kulturne rastline' - 'jed iz užitnega dela kulturne rastline' (števno- = snovno) (melancana $)^{20}$

Sinekdohni pomeni

1.'drevo' - 'les' (števno- = snovno) (balza, brest, gaber, hikori, javor, jesen, macesen, mahagoni, mahagonovec, palisander, sandal, tik itd.)

2. 'žival' - 'krzno' (števno- = snovno) (hermelin, nerc, norka, kuna, ponorka, lisica)

3. 'žival' - 'meso' (števno- = snovno) (bekon; piščanec, puran, zajec, srna, kura; koštrun, losos, polh)

4. 'del človeškega telesa za opravljanje določene funkcije' - 'opravljanje funkcije' (števno- = pojmovno) (nos, roka, glava, oko, uho, srce)

${ }^{19}$ Zaradi verodostojnosti $\mathrm{v}$ pogledu leksikaliziranosti dane pomenske povezave so navedeni samo tipi pomenskih povezav, dobljeni pri sistematični obdelavi 2763 samostalniških znotrajleksemskih medpomenskih razmerij pri samostalnikih črk G, M, R in Ž v SSKJ; nekateri tipi medpomenskih povezav, ugotovljeni po drugih, priložnostnih načinih (navedbe v strokovni literaturi, naključno odkriti tipi $\mathrm{v}$ gradivu), pa so navedeni samo, če imajo potrdilo $\mathrm{v}$ gradivu (SSKJ, besedilni korpus Nova beseda, novejše gradivo Leksikološke sekcije ISJ). Glede na to je treba pričakovati, da v tipologiji ni naveden kateri od razmeroma pričakovanih tipov; prav tako je na osnovi gradivskega preverjanja pri ponazorilih lahko izostal leksem, pri katerem se regularno pričakuje določeni tip medpomenske povezave.

${ }^{20}$ Primer melancana je izjemen in delno ustreza tej skupini; praviloma je namreč motivirajoči pomen za 'jed' poimenovanje, vključujoče KPS števno- (snovno) (rostbif, file, sekanica; blitva, solata, špinača, mangold, repa, ribez), ki se v tem pomenu regularno povezuje s slovničnim številom ednino. Lahko pa primer melancana služi kot opozorilo, da je povezava med kategorialno pomensko lastnostjo števnostjo in slovničnim številom pri poimenovanjih kulturnih rastlin in pri njihovih motiviranih pomenih delno predvidljiva, vendar ne do stopnje avtomatizma. Tako bi pri melancana moral slovarski opis s stališča števnosti vključevati te podatke: 1. 'enoletna kulturna rastlina s temno zelenimi dlakastimi listi in stebli in vijoličastimi jajčastimi sadovi' (gojiti melancane; nasad melancan; čas obiranja melancan in paprike); kategorialna lastnost števnost: vsebovanje KPS števno-; slovnično število, s katerim je izražena ta lastnost $\mathrm{v}$ tem pomenu: množina 2. 'sad te rastline' (odtrgati melancano; narezati melancano na rezine); kategorialna lastnost števnost: KPS števno+ 3. 'jed iz tega sadu' (jesti melancane; ne marati melancan); kategorialna lastnost števnost: KPS števno-; slovnično število, s katerim je izražena ta lastnost v tem primeru: množina. Prim o tej problematiki Mel'čuk 1985: 257-264. 
5. 'predmet kot znamenje delovanja, stanja' - 'delovanje, stanje' (števno- = pojmovno) (žezlo)

$$
\begin{aligned}
& \text { 5.3.2 Pomenske izpeljave, vključujoče spremembo KPS števno- } \rightarrow \text { števno+ } \\
& \text { 5.3.2.1 števno- }\{\text { pojmovno }\} \rightarrow \text { števno+ }
\end{aligned}
$$

Metonimični pomeni

1. 'dejanje' - 'vršilec dejanja' (administracija, admiraliteta, agentura, aktiv, asistenca, aviacija, avtoprevozništvo, grabež, gverila, menedžment, manufaktura, medicina, obramba, razsodništvo, reakcija, radiodifuzija, radio, radiotelevezija, ravnateljstvo, režim, vodstvo, železnica) ${ }^{21}$

2. 'dejanje' - 'predmet za dejanje' (reklama) ${ }^{22}$

3. 'stanje' - 'nosilec stanja' (dremě̌, eksistenca, nevera)

4. 'stanje' - 'vzrok stanja' / 'povzročitelj stanja' (razočaranje; nesreča, nevarnost, radost, razhajanje $)^{23}$

5. 'lastnost' - 'nosilec lastnosti' (grdoba, hudoba, gracija, lenoba, malopridnost, mediokriteta, nečimrnost, nesramnost, neumnost, žalost, žlehtnoba, življenje; genij, talent zaradi izpeljave 'sposobnost za kaj' - 'človek, ki ima to sposobnost'; domino, maska, noša zaradi izpeljave : 'oblačilo' - 'človek, ki ima to oblačilo')

6. 'lastnost' - 'predmet nosilec lastnosti' (1. čudaštvo, grobost, ljubeznivost, malopridnost, modrost, nasilništvo, nesramnost, neumnost, nežnost, odgovornost, predrznost, prijaznost, prisrčnost, vljudnost; 2. absurdnost, aktualnost, dobrina, majhnost, malost, mehčava, melodija, modrost, neokusnost, neprijetnost, neumnost, nevšečnost, neznanost, ničevost, ničnost, novost, objektivnost, omejenost, pojavnost, pojmovnost, pomanjkljivost, posameznost, pravljičnost, nagota, prijetnost, prikritost, privlačnost, razsežnost, radikalnost, različnost, rariteta, razkošje, razkošnost, reakcionarnost, redčina, redkost, relativnost, resničnost, skupnost, specialnost, splošnost, subjektivnost, subtilnost, svežina, telesnost, teža, toplina, transcendenca,

${ }^{21}$ Čisti vzorec z razmerjem 'dejanje' (KPS človeško-) - 'vršilec dejanja' (KPS števno+, in sicer človeško+) ima malo uresničitev. Pogostejši so primeri, ko je 'vršilec dejanja' individualen ali skupinski ali samo skupinski, zlasti v pomenu 'delovni kolektiv' (skupina, skupnost zaposlenih); to je povezano $s$ spremembo, da je $v$ teh primerih tudi pomen 'dejanje' nadomeščen $s$ pomenom 'dejavnost', temu ustrezno pa 'vršilec dejanja' s pomenom 'opravljavec dejavnosti'. Ugotovljeno bi lah ko služilo kot dopolnjevalno določilo kategorialne pomenske lastnosti človeško: Samostalnik ima v danem pomenu kategorialno pomensko sestavino človeško+, če je lahko v vlogi vršilca dejanja, vendar nima pomena 'skupina', 'skupnost'.

${ }^{22}$ Primeri, ki bi v tolikšni meri kot reklama ustrezali dvojici 'dejanje' - 'predmet za dejanje', so redki. Težko jih je ločevati od bližnjih pomenov 'rezultat dejanja' ( $r o j)$, 'predmet dejanja' (raz$s a d$ ), 'orodje dejanja' (žvižga; Žvižga oddaja lepe glasove 'predmet za dejanje' - piskati na žvižgo 'orodje dejanja'), 'sredstvo dejanja' (dokumentacija ('kar kaj izpričuje' ali pa 's čimer se kaj izpričuje'), argumentacija, negacija, numeracija) in 'vzrok/povzročitelj dejanja' (žalitev). Prim. še razlaga, rešitev, zamenjava.

${ }^{23}$ Ta pomenska dvojica je možna tudi brez spremembe v števnostni KPS: gorje, lakota, žeja ipd. Iz tega je mogoče sklepati, da se sprememba v smislu pojavitve KPS števno+ pojavi zlasti takrat, ko so možne številne različne konkretizacije za pomen 'vzrok' ali 'povzročitelj'; za tak pomen je potrebno poimenovanje s poudarjenim pomenom posameznosti, kar se konkretizira v KPS števno+. 
transcendentalnost, tujstvo, tukajšnjost, udobnost, ugodnost, umetnost, umišljenost, uradnost, verjetnost, vsakdanjost, vzporednost, zakonitost, zanimivost, zaupnost, zoprnija, zoprnost, žalost)

1. Redakcija leksema neumnost iz Slovarja slovenskega knjižnega jezika opozarja na glavne značilnosti medpomenske povezave 'lastnost' - 'predmet nosilec lastnosti':

neúmnost -i ž: 1. 'lastnost neumnega človeka': Njegovo neumnost so hitro opazili / obžalovati neumnost odločitve ... 2. ekspr. 'neumno govorjenje ali ravnanje': Ta prepoved se mu je zdela neumnost / govoriti neumnosti; počenjati, uganjati neumnosti... // 'kar je neumno sploh': Take neumnosti še nisem bral, gledal / Napolnili so mu glavo z neumnostmi 'neumnimi nazori, mislimi'

Pomen 'lastnost' v motivirajočem pomenu je lahko omejen s pripisovanjem lastnosti določeni odnosnici ('lastnost neumnega človeka') ali pa ne (absurdnost: 'lastnost, značilnost absurdnega'); pri lastnostih, tipičnih za človeka, je omejitev navadno navedena (607 pomenov v SSKJ ima izpisano razlago 'lastnost človeka'), in $\mathrm{v}$ teh primerih je motivirani pomen predvidljiv $\mathrm{v}$ okviru 'govorjenje / ravnanje / vedenje / dejanje'. Prehod od KPS števno- $v$ motivirajočem pomenu v KPS števno+ $v$ motiviranem pomenu je razviden iz ponazarjalnih zgledov, razlaga pa ni vedno toliko natančna, da bi upoštevala to razliko. $\mathrm{V}$ razlagi obeh pomenov je tako prikazan metonimični prehod iz pomena 'lastnost' (KPS števno-) v pomen 'kar ima tako lastnost', nadaljnje določanje metonimičnega 'kar' pa je preneseno $\mathrm{v}$ ponazarjalne zglede, $\mathrm{v}$ razlagi pa samo okvirno nakazano z možnostmi, ki so npr. v zvezi s človeškimi lastnostmi najbolj pogoste ('ravnanje' / 'vedenje' / 'dejanje' / 'govorjenje'). ${ }^{24}$

2. Na podoben način ožje predvidljiv motivirani pomen 'predmet nosilec lastnosti' imajo še nekateri samostalniki, npr. samostalniki iz pridevnikov za barve pomen 'omejena površina take barve' (belina, črnina, črnjava, modrina, rumenina, rdečina, rjavina, sinjina, sivina, zelenina, zlatnina), sicer pa je ta predvidljivost nasploh omejena s pomenom najbolj tipičnega samostalnika, ki se mu pripisuje v motivirajočem pomenu imenovana lastnost (golota: 'kar je golo': Velik izrez je kazal precej golote $=$ 'gole kože'). Slovarske razlage so $\mathrm{v}$ tem pogledu različne, ker upoštevajo morebitno leksikaliziranost poimenovanja točno določene zunajjezikovne danosti z izlastnostnim samostalnikom in $\mathrm{v}$ tem primeru iz razlage niti ni več razvidna metonimična povezanost pomenov. ${ }^{25}$ Veči noma vsebuje pomen 'predmet nosilec lastnosti' KPS števno+, kar je v slovarskem prikazu nakazano z zgledom (iz same razlage 'kar je tako ...' števnost ni razvidna), nekateri redki primeri pa imajo izkazana dva pomena za 'predmet nosilec lastnosti', in sicer abstraktni pomen s KPS števno- (lepota: 'kar je lepo' čut za lepoto), in konkretni pomen s KPS števno+ ('lepa stvar': naravne lepote).

${ }^{24}$ Hočevar Gregorič 1995: 454, hvali rešitve v SSKJ, pri katerih so s števnostnimi razlikami povezane pomenske spremembe prikazane tudi v razlagah (prijaznost: lastnost - dejanje, ravnanje, prilizljivost: lastnost - besede, irazi, pikantnost: lastnost - dogodek); v zahtevi, da »sodijo na prvo mesto neštevni zgledi, torej pri prijaznost najprej iztržek zahvaljujem se vam za to prijaznost, in šele potem izkazovati komu prijaznosti «, pa ne upošteva, da besedilni iztržek v tem primeru ne zadošča za določitev števnostne lastnosti; zares je v prvem zgledu prijaznost v ednini, kar pa ne onemogoča pomena 'prijazno dejanje', ki vsebuje KPS števno+, enako kot v drugem zgledu; torej oba navedena zgleda lahko ponazarjata pomen s KPS števno+, v slovarskem sestavku pa sta pravilno razvrščena po pravilu, da so pri samostalniku zgledi za brezpredložno rabo pred zgledi za predložno rabo.

${ }^{25} \mathrm{Npr}$. pri leksemu pomanjkljivost so vsi pomeni metonimično izpeljani iz pomena 'lastnost', iz razlag pa vsaj na prvi pogled to ni razvidno. Takih primerov je med zgoraj navedenimi še nekaj. - J. Meze na narečnem gradivu nekaterih govorov na Pivškem ugotavlja, da so mnogi abstraktni samostalniki živi samo $\mathrm{v}$ motiviranem pomenu, leksikaliziranem za poimenovanje točno določenega pojma, predmeta, osebe, brez izhodiščnega lastnostnega pomena, npr. pobožnost 'cerkveno opravilo', smrkavost 'konjska bolezen', splahota 'plašen človek', grenkoba 'grenka pijača', grdoba 'slab človek' in 'grd, slab travnik', sladkoba 'sladka jed, pijača'. (Meze 1959: 36) 
7. 'dejanje' - 'predmet dejanja' (anketa, aplikacija, aprovizacija, doživetje, fantaziranje, izbor, izpis, korektura, kosilo, nakup, občutek, občutje, pletenje, ral, razsad, razstava, recitacija, recitativ, šivanje, učenje, žrtev) ${ }^{26}$

Primeri so težko ločljivi od tistih pri 'dejanje' - 'rezultat dejanja', kar je nakazano celo v slovarski razlagi 'kar se plete, je spleteno' pri pletenje:

1. 'glagolnik od plesti': ukvarja se s pletenjem; bombaž, volna za pletenje; kvačkanje in pletenje / ročno, strojno pletenje / pletenje košar 2. 'kar se plete, je spleteno': ko je prišel, je odložila pletenje

8. 'dejanje' - 'drugi predmet dejanja' (dopolnitev, oprema)

Primere je težko razmejiti od pomena 'predmet za dejanje' (oprema: kar kaj opremlja, kar kaj dopolnjuje) ali 'orodje / sredstvo za dejanje' (s čimer se kaj opremlja, dopolnjuje).

9. 'dejanje' - 'rezultat dejanja' (abstrakcija, aerofotografija, agregacija, alegorija, asociacija, obeležba, groteska, dognanje, dramatizacija, harmonizacija, gradnja, makrame, makrofotografija, malaríja, mikrofotografija, misel, novelistika, pisanje, nakup, konstrukcija, recept, recenzija, razglas, rekonstrukcija, reprodukcija, rez, ${ }^{27}$ reportaža, retuša, retrospektiva, resolucija, reminiscenca, redukcija, reptura, risanje, razdejanje, razčlemba, razodetje, razprava, agregacija, realizacija, razval, razvod, reakcija, reeskont, rezervacija, redakcija, risarija, rimarija)

Skupina 'dejanje' - 'rezultat dejanja' je na ravni denotativne pomenskosti precej raznolika, zato so števnostne razlike pri pomenu 'rezultat dejanja' uporabno razvrstitveno merilo. Med motiviranimi pomeni 'rezultat dejanja' močno prevladujejo pomeni s KPS števno+. Neštevni obsegajo tri skupine: 1. 'stanje' (pojmovno), npr.: razporeditev, razdejanje, razmestitev, razvrstitev; 2. 'snov' (snovno): žaganje, žamanje, rast (tudi skupno); 3. 'izdelek, ki obsega skupino enot kot celoto' (skupno): romanopisje.

V skupino 'dejanje' - 'rezultat dejanja' se uvrščajo tudi nekateri leksemi, pri katerih pomen 'dejanje' ni površinsko razvidno tvorjen iz glagola. ${ }^{28}$ Npr.: akvarel: 'slikarska tehnika, pri kateri se slika na papir s prosojnimi vodenimi barvami': Slikar goji akvarel že od mladosti // 'slika v tej tehniki': Na steni visijo akvareli; razstava akvarelov; olje: 'slikarska tehnika, pri kateri se slika z oljnatimi barvami' // 'slika v tej tehniki': razstava olj; olja in akvareli. Navedena primera nakazujeta znotraj tipa 'dejanje' - 'rezultat dejanja' obstoj podtipa 'umetniško oblikovanje po določenem načinu' - 'umetniško delo, ki nastane pri tem oblikovanju' (akvatinta, enkavstika, grafika, ${ }^{29}$ gra-

${ }^{26}$ Pri obravnavi slovničnih števil ednine in množine kot izrazila števnostne opredelitve v zvezi s pojmovnimi imeni Hočevar Gregorič (1995) ne prepoznava posebej pomenske spremembe 'dejanje' - 'predmet dejanja' oz. 'rezultat dejanja', pač pa ima za te vrste primere zastavljeni pomenski skupini 'ponovljivost in večkratnost' in 'individualizacija' (Hočevar Gregorič 1995: 445). Tako tudi $\mathrm{v}$ komentarju $\mathrm{k}$ slovarskemu prikazu pri predvidenje pri zgledu njegova predvidenja se niso uresničila (nasproti zgledu predvidenje nesreče) le pogreša večje samostojnosti $\mathrm{v}$ slovarskem prikazu, sicer pa pomenske spremembe ne opredeljuje (453).

${ }^{27}$ Pri pomenu 'rezultat dejanja' izglagolskih samostalnikov s pomenom 'deformirati, poškodovati' (urez, zlom, prelom) Apresjan omenja možnost prepletanja pomena 'rezultat dejanja' in 'mesto dejanja' (*Pri urezu je prišlo do krvavitve. - *pokriti urez z obližem). (Apresjan 1995: 197) Gradivo v SSKJ tega ne kaže.

${ }^{28}$ Slovarske redakcije morajo biti tudi v tem primeru na poseben način brane, da se pokaže metonimična povezanost pomenov na ravni 'dejanje / dejavnost' - 'rezultat dejanja'. Tako je $\mathrm{v}$ to skupino mogoče uvrstiti tudi na prvi pogled nepovezana pomena pri arhitektura: 'dejavnost, pri kateri se estetsko oblikuje prostor': Arhitektura mora upoštevati statične zakonitosti - 'stvaritev / stvaritve te dejavnosti' (v SSKJ: 'kompleks arhitekturnih stavb, objektov z značilnostmi določene dobe'): ljubljanska baročna arhitektura (števno-, skupno); ogledati si nekaj arhitektur v kamnu (števno+).

${ }^{29} \mathrm{~V}$ nekaterih primerih je rezultat dejanja tudi števno-, in sicer skupno: grafika: razstava grafike 'grafičnih izdelkov'; poezija: objaviti vso pesnikovo poezijo 'pesniška dela'. 
vura, gvaš, kolaž, lepljenka, litografija, olje, praskanka, sgraffito, trganka, arhitektura, poezija, glasba). ${ }^{30}$

10. 'dejanje' - 'sredstvo dejanja' (dovod, pogon)

Pomen 'sredstvo dejanja' sicer vključuje dve skupini pomenov: 1. 'snov' (števno-) (polnilo, premaz) in 2. 'naprava / celota naprav' (števno+ (dovod) / števno- (skupno))(ventilacija, napeljava, vzmetenje, dokumentacija).

11. 'dejanje' - 'mesto dejanja' (1. prehod, dovoz, izstop, izvoz, odvoz, prehod, privoz, sestop, uvod, vstop, vtok (tvorjenke iz premikanjskih glagolov); 2. izkop, izliv, iztok, kritje, odkop, razcep, razliv, raztok, razsad, rez, zajetje)

Podskupino predstavljajo samostalniki z motivirajočim pomenom 'dejavnost': receptura: 'izdelovanje zdravil po zdravnikovem receptu' - 'lekarniški oddelek za tako izdelovanje zdravil'. Pri netvorjenkah oz. neavtohtonih tvorjenkah je pomenska povezava na prvi pogled manj razvidna Prim. še aseptika, administracija, anglistika, ambulanta, galvaniziranje, karantena, kramarija, noviciat, rentgen, županstvo, računovodstvo, redakcija, trgovina.

12. 'dejanje' - 'obred, vključujoč to dejanje' (daritev, darovanje)

13. 'dejanje / dogodek / stanje' - 'dokument o tem' (sporazum, absolutorij, diploma, koncesija, mnenje, objava, račun, razglas, razpis, recept, resolucija, rezervacija, rodovnik)

14. 'ples (način premikanja)' - 'skladba za ples' (bolero, bossa nova, bugivugi, kalipso, čačača, čarlston, fokstrot, galop, gavota, habanera, karioka, krakovjak, madison, mambo, menuet, onestep, pavana, rokenrol, rumba, samba, segidilja, šimi, šotǐs, štajeriš, tango, tvist, valček; polka, kazačok, mazurka, poloneza, ragtime; sarabanda, giga $)^{31}$

15. 'vsebina' - 'knjiga s to vsebino' (pravopis, brevir, časoslov, nomenklatura, register)

Sinekdohni pomeni

1. 'pojav, vključujoč značilno predmetnost' - 'predmetnost' (razstava, muzej, rent-a-car)

2. 'dejanje, dejavnost, stanje, vezano na določen predmet' - 'predmet' (gol, ristanc)

3. 'politična ureditev države' - 'država s to ureditvijo' (monarhija)

4. 'način sklanjanja določene vrste samostalnikov' - 'samostalnik iz te vrste' (femininum, maskulinom, nevtrum)

\subsubsection{2 števno- $\{$ snovno $\} \rightarrow$ števno+}

Metonimični pomeni

'snov' - 'izdelek iz snovi'

a) 'snov' - 'nedoločen izdelek iz snovi’ (guma, železo, steklo)

b) 'snov' - 'določen izdelek iz snovi' (asfalt, mavec)

${ }^{30} \mathrm{~V}$ tip 'dejanje' - 'rezultat dejanja' tudi Filipec uvršča (imenuje jih varianta produktivnega podtipa 'dejanje' - 'rezultat dejanja'): architektura, grafika, hudba, kinematografie, poezie, režie, sochařství. (Filipec 1986: 115)

${ }^{31}$ Zunaj tega vzorca, torej brez motiviranega pomena 'skladba', ostajajo plesi, pri katerih je iz razlage razvidno, da so razločevani zlasti s posebnimi gibalnimi figurami, in ne sompozicijskimi značilnostmi (četverka / kadrilja, kotiljon, rezijanka, tarantela, vrtec). 
c) 'snov' - 'umetniški izdelek iz snovi' (bron, bronsa, terakota, fajansa, mavec)

č) 'tkanina' - 'oblačilo iz tkanine' (raševina) ${ }^{32}$

d) 'snov' - 'določena (osamosvojena) količina snovi' (aspirin, nefrit (vključno s celot-

no pomensko skupino 'kamnina' - 'okrasni kamen'))

5.3.3 Pomenske izpeljave, vključujoče spremembo KPS znotraj števno-

5.3.3.1 pojmovno $\rightarrow$ skupno

1. 'dejanje' - 'drugi predmet dejanja' (oprema, hlajenje)

2. 'dejanje' - 'rezultat dejanja' (romanopisje)

3. 'čas' - 'obstoječe v času' (aluvij, antika, minulost, preteklost)

\subsubsection{2 pojmovno $\rightarrow$ snovno}

1. 'dejanje' - 'rezultat dejanja' (žaganje)

2. 'dejanje' - 'sredstvo dejanja' (premaz)

3. 'vinska trta (vrstno poim.)' - 'vino' (barbera, črnina, direktor (žarg. samorodnica), frankinja, garganija, izabela, kabernet, kavčina, kraljevina, malvazija, merlot, muškat, muškatelec, pikolit, pinela, plavec itd., vse vrste vinske trte)

\subsubsection{Pomenske izpeljave, vključujoče spremembo znotraj KPL človeško}

\section{Metonimični pomeni}

Nekateri metonimični tipi s spremembo človeško- $\rightarrow$ človeško+ so že navedeni v okviru skupine števno- $\rightarrow$ števno+ pri 5.3.2.1:

1. 'dejanje' - 'vršilec dejanja',

2. 'stanje' - 'nosilec stanja',

3. 'lastnost' - 'nosilec lastnosti'.

Med metonimijami se jim pridružuje še tip:

4. 'predmet' - 'upravljavec predmeta', izkazan s podtipom 'glasbeni instrument' 'izvajalec na tem instrumentu' (violina: igrati (na) violino - Violine so bile v nocojšnjem koncertu odlične).

\section{Sinekdohni pomeni}

1. 'del telesa' - 'človek glede na ta del' (gobezdalo, goflja, gobec, zijalo, trobilo, čeljust, duh, duša, avtoriteta)

2. 'glas pevca' - 'pevec z glasom' (alt, tenor, bas)

\footnotetext{
${ }^{32}$ To je v SSKJ eden redkih primerov, ki nakazuje to metonimijo. SSKJ ima med 189 leksemi s pomenom 'tkanina' naveden ponazarjalni zgled biti oblečen $v X$ ali obleči se $v X$ še pri baržun, batist, škrlat, žamet, bager, ki se jim pridružuje še biti $v X-u$ pri tvid, biti zavit $v X$ pri svila in nositi $X$ pri sintetika. Vsi ti zgledi zaradi skladenjsko ozko omejene rabe ne potrjujejo popolnega uslovarjenega metonimičnega samostalniškega pomena, saj so vsi vezani na skladenjsko vlogo vezljivostnega določila (biti oblečen $v$ svilo) in s tem ostajajo zunaj samostalniške kategorialnosti. Samostalniški bi bil zgled: *Pomerila je dve svili 'svileni obleki'. Bolj pričakovana bi bila raba s kategorialno lastnostjo skupno: *V garderobi ima samo svilo 'svilena oblačila'. Gradivo, tudi poleg SSKJ (Fida, Nova beseda), ne potrjuje nobenega od njiju.
} 
3. ‘čin / naziv' - 'nosilec čina / nosilec naziva' (general, magister, maršal, generallajtnant, generalmajor, marešalo, major)

Metaforični pomeni

1. ‘žival' - 'človek' (golobičica, gad, glista, golobica, gorila, gos, gosenica, govedo, maček, mačica itd.)

2. 'mitološko bitje' - 'človek' (gigant, angel, harpija, hudič, palček)

3. 'stanje' - 'človek' (nesreča, griža, pokora)

4. 'izloček' - 'človek' (gnoj, govno, gnida, grinta)

5. 'predmet $\mathrm{z}$ določeno fizikalno lastnostjo' - 'človek $\mathrm{z}$ določeno vedenjsko lastnostjo' (motovilo, goba, trlica, brus)

6. 'prvina zemljepisne oblikovanosti' - 'človek' (gora, skala)

\section{Kratice}

KPL kategorialna pomenska lastnost

KPS kategorialna pomenska sestavina

RPS razločevalna pomenska sestavina

UPS uvrščevalna pomenska sestavina

SSKJ Slovar slovenskega knjižnega jezika

\section{Literatura}

APRESJAN, Ju. D., 1995: Leksičeskaja semantika. Moskva: Vostočnaja literatura RAN.

- - 1974: Regular Polysemy. Linguistics 142. 5-32.

Collins Cobuild English Language Dictionary. London 1992: Cobuild.

CRYSTAL, D., 1991: A Dictionary of Linguistics and Phonetics. Oxford: Blackwell.

DERGANC, A., 1991: O (ne)števnosti poimenovanj za zelenjavo, sadje in jagode v slovenščini in ruščini. Slavistična revija 39/3. 277-283.

FILIPEC, J., ČERMÁK, F., 1985: Česká lexikologie. Praha: Academia.

HOČEVAR GREGORIČ, M., 1995: Slovenski neštevni samostalniki in njihova obravnava v SSKJ. Slavistična revija 43/4. 441-458.

JAKOBSON, R., 1989: Lingvistični in drugi spisi. Ljubljana: ŠKUC, Filozofska fakulteta.

KOZLEVČAR, I., 1968: O pomenskih kategorijah samostalnika v povedkovi rabi. Jezik in slovstvo XIII, 1. 11-16.

- - 1974: Slovnično število in pomenske kategorije samostalnika. 10. seminar slovenskega jezika, literature in kulture. Ljubljana: Filozofska fakulteta. 31-39.

MELČUK, I. A., 1985: Semantičeskie osobennosti »isčisljaemyh« suščestvitelnyh v russkom jazyke $\mathrm{i}$ ih leksikografičeskoe opisanie. Poverhnostnyj sintaksis russkih čislovyh vyraženij. Wiener slawistischer Almanach 16. Wien. 257-264. 
MEZE, J., 1959: O abstraktih iz pridevnikov. Razprave drugega razreda SAZU V. Ljubljana: Slovenska akademija znanosti in umetnosti. 32-45.

OREŠNIK, J., 1972a: Formalizacija semantičnih definicij najmanjših jezikovnih enot s pomenom. Problemi semantike, sintakse in obravnave tekstov. Ljubljana: Inštitut Jožef Štefan. 27-33.

Slovar slovenskega knjižnega jezika: Elektronska izdaja v 1.0. 1998. Ljubljana: DZS.

Slovenski pravopis. Ljubljana 2001: SAZU in ZRC SAZU.

SNOJ, J., 2002a: Tipologija slovarske večpomenskosti. Magistrsko delo. Filozofska fakulteta Univerze v Ljubljani. Tipkopis.

- - 2002b: Nekatere značilnosti slovarskega sestavka novega Slovenskega pravopisa. 38. seminar slovenskega jezika, literature in kulture. Ljubljana: Univerza $\mathrm{v}$ Ljubljani.

- - 2004: Tipologija slovarske večpomenskosti slovenskih samostalnikov. Ljubljana: Založba ZRC.

TOPORIŠIČ, J., 1966: Slovenski knjižni jezik 2. Maribor: Založba Obzorja.

- - 1974: Stilnost oblikoslovnih kategorij slovenskega knjižnega jezika. Slavistična revija 22/2. 245-262.

- - 1975: Esej o slovenskih besednih vrstah. Jezik in slovstvo 20, 8. 295-305.

- - 1976: Slovenska slovnica. Maribor: Založba Obzorja.

- - 1981: K teoriji spola v slovenskem (knjižnem) jeziku. Slavistična revija 29/1. 79-94.

- - 1982: Nova slovenska skladnja. Ljubljana: Državna založba Slovenije.

- - 2000: Slovenska slovnica. Maribor: Založba Obzorja.

VIDOVIČ MUHA, A., 1992: Slovnična obvestilnost Slovarja slovenskega knjižnega jezika. Zbornik Slavističnega društva Slovenije. 35-49.

- - 2000: Slovensko leksikalno pomenoslovje: Govorica slovarja. Ljubljana: Znanstveni inštitut Filozofske fakultete (Razprave Filozofske fakultete).

ŽIC-FUCHS, M., 1991: Znanje o jeziku i znanje o svijetu. Semantička analiza glagola kretanja u engleskom jeziku. Zagreb: Filozofski fakultet.

Prispelo septembra 2004, sprejeto decembra 2004

Received September 2003, accepted December 2004

Kategorialne pomenske lastnosti in tipologiziranje slovarske večpomenskosti

Kategorialni pomen, prepoznan kot obvezna sestavina slovarskega pomena, se uresničuje preko kategorialnih pomenskih lastnosti oz. kategorialnih pomenskih sestavin. Skladenjskofunkcijska opredelitev kategorialne pomenske lastnosti vzpostavlja povezavo med kategorialnimi pomenskimi lastnostmi in besednimi vrstami. Dana množica poimenovalnih prvin je namreč preko vsebovanega nabora določenih kategorialnih pomenskih lastnosti nosilka določene skladenjske vloge in s tem konkreti- 
zacija besedne vrste. Kategorialne pomenske lastnosti samostalnika so npr. spol, podspola živost in človeškost, števnost in sklanjatev.

Tvorbno neposredno povezana pomena večpomenskega samostalniškega leksema se lahko medsebojno razlikujeta glede na to, da vsebujeta eno od nasprotnih KPS, uresničujočih določeno KPL. Npr. v leksemu čéšnja -e ž se pomena 'drevo' in 'les drevesa' tipološko razlikujeta $\mathrm{v}$ tem, da je KPL števnost $\mathrm{v}$ pomenu 'drevo' uresničena s KPS števno+ in v pomenu 'les' s KPS števno-. Neposredne pomenske izpeljave, ugotovljene znotraj večpomenskih leksemov, je mogoče tipologizirati glede na to, katero od sprememb na ravni KPS vključujejo. V sestavku so prikazani tipi samostalniških pomenskih izpeljav (ugotovljeni na 2763 samostalniških znotrajleksemskih medpomenskih povezavah, izkazanih v Slovarju slovenskega knjižnega jezika), ki vključujejo spremembe na ravni KPL števnosti (1. števno+ $\rightarrow$ števno-; 2. števno- $\rightarrow$ števno+; 3. spremembe znotraj števno-: pojmovno $\rightarrow$ skupno, pojmovno $\rightarrow$ snovno) in človeškosti (4. človeško- $\rightarrow$ človeško+).

\section{Categorial semantic properties and the typologization of lexical polysemy}

The categorial meaning, considered an immanent component of the lexical meaning, is realized through categorial semantic properties, that is to say, categorial semantic features. The syntactic-functional definition of categorial semantic properties establishes the link between categorial semantic properties and word classes. That is to say, the given group of lexemes goes beyond the aggregate of the particular categorial semantic features as the carrier of the specific syntactic role and thus the concretization of the word class. The categorial semantic properties of the noun are, for example, gender, the subgenders animacy and humanness, countability, and declension.

Two meanings of a polysemantic lexeme, belonging to directly motivated polysemy, can differ from one another depending on whether they contain one of the opposing categorial semantic features (CSF). For example, in the lexeme čéšnja -e, fem. 'cherry', the meanings 'tree' and 'wood of the tree' differ typologically in that the CSP of countability in the meaning 'tree' is realized with the CSF + count and in the meaning 'wood' with the CSF - count. Direct semantic derivations found in polysemantic lexemes can be typologized taking into consideration the change on the level of CSF. The paper shows the types of noun semantic derivations (from 2,763 nouns attested in the Dictionary of Standard Slovene), including changes on the level of the CSP of countability (1. + count $\rightarrow$-count; 2 . -count $\rightarrow+$ count; 3 . changes internal to -count (abstract $\rightarrow$ collective, abstract $\rightarrow$ mass) and humanness (4. -human $\rightarrow$ +human). 